\title{
Flow-cytometric Studies of the Phagocytic Capacities of Equine Neutrophils
}

\author{
By A. Johannisson ${ }^{1}$, G. Gröndahl ${ }^{2}$, S. Demmers ${ }^{2}$ and M. Jensen-Waern ${ }^{2}$ \\ ${ }^{1}$ Department of Pathology, and ${ }^{2}$ Department of Medicine and Surgery, Faculty of Veterinary Medicine, Swedish \\ University of Agricultural Sciences.
}

\begin{abstract}
Johannisson A., G. Gröndahl, S. Demmers and M. Jensen-Waern: Flow-cytometric studies of the phagocytic capacities of equine neutrophils. Acta vet. scand. 1995, 36, 553-562. - Methodological aspects of flow-cytometric evaluation of the phagocytic properties of equine neutrophils were elucidated. The kinetics of attachment and ingestion were studied, and the phagocytic process was more rapidly completed when serumopsonized yeast cells were used than with use of IgG-opsonized yeast cells. Trypan blue was successfully used to quench fluorescence of non-ingested yeast cells. There were only minor differences in the kinetics of phagocytosis between quenched and unquenched samples, indicating that attachment is rapidly followed by ingestion. Trypan blue quenching caused loss of cells with light scattering properties of granulocytes, although this did not affect the determined frequencies of truly phagocytic neutrophils. Aggregation of yeast cells proved to be a disturbance but not an obstacle to the determination of frequencies of actively phagocytic cells. Flow cytometry is well suited for studies of phagocytosis of yeast cells by equine neutrophils, and the trypan blue quenching provides a means of eliminating false-positive events due to aggregation of yeast cells. The main advantage of the flow-cytometric method is the possibility of rapid processing of a large number of samples, making the method useful for studies of herds.
\end{abstract}

horses; granulocytes; trypan blue quenching; adhesion; kinetics; ingestion; fluorescence; yeast cells; opsonization.

\section{Introduction}

Bacterial infections often cause considerable problems in horses, especially in young foals, where the frequency of infection may suggest an immature host defence mechanism (McGuire et al. 1977, Morris et al. 1987, Prescott 1993). Infections in foals often have a fatal outcome (Platt 1973). The neutrophil is a part of the early, non-specific immune response in all mammals, which is essential in defending the host against microbial invasion (Stossel 1974, Root \& Metcalf 1977, Babior 1978).

A number of in vitro assays for evaluating the phagocytic capacity of neutrophils have been described. In horses, this capacity has been studied by light microscopy (Bernoco et al. 1987) and flow-cytometric methods (Foerster $\&$ Wolf 1990 ). The killing capacity of neutrophils has been assessed by chemiluminescence assays (Jacobsen et al. 1982, Leblanc \& Pritchard 1988, Magnusson \& Jonsson 1991) and nitroblue tetrazolium dye reduction tests (Takai et al. 1986).

Major drawbacks in many of the described approaches for determination of the phagocytic capacity are the laborious and time-consuming methods for preparation of neutrophils and for manual analysis of the phagocytosis results. This applies both to visual methods (using light 
or fluorescence microscopy) and plating techniques (where remaining viable colonies of target bacteria are counted). Problems with objective quantitation and observer error may be encountered. Moreover, preparation of neutrophils by density gradient centrifugation may result in selection of a cellular sub-population and/or modulation of receptor functions, rendering a different response (Jacobsen et al. 1982, Hed et al. 1987).

Flow cytometry (FCM) is a method used for rapid analysis of the properties, constituents and functions of individual cells in suspension. FCM is used routinely in human medicine, e.g. for the monitoring of AIDS patients (Calvelli et al. 1993) and for leukaemia immunophenotyping (Campana 1994). A large number of different samples can be rapidly processed. The cells are passed single-file through an illuminating laser beam. Laser light scattered by the cells indicates the size and internal complexity of the cells. The phagocytic capacity of neutrophils has been studied with FCM in both humans (Hed \& Stendahl 1982, Bjerknes \& Bassøe 1984) and animals (Matsson et al. 1985, Saad \& Hageltorn 1985, Thuvander et al. 1987, Jensen-Waern et al. 1994), including horses (Foerster \& Wolf 1990). Bacteria, fungi or microspheres have been used as the material to be phagocytosed. Serum and IgG have been used as opsonins (Jensen-Waern et al. 1994). C3b is considered to be the main opsonic factor in serum (Hed \& Stendahl 1982).

The aim of the present study was to further develop a flow cytometric model for analysis of the phagocytic capacity of equine neutrophils, which could be useful for herd investigations as well as for other studies with a large number of samples. The neutrophils were allowed to phagocytose fluorescent yeast cells opsonized with either pooled serum or IgG. The fluorescence of non-ingested yeast cells was quenched with trypan blue, and the quenching kinetics, the ef- fect of quenching on the percentage numbers of neutrophils, and the proportion of neutrophils with ingested yeast cells after quenching, were elucidated. The attachment and ingestion kinetics were also studied, and the problems posed by aggregation of yeast cells were addressed.

\section{Materials and methods \\ Animals}

For studies of the kinetics and quenching dynamics of the phagocytosis model, 5 Standardbred mares (age 7-20 years) were used. The horses were clinically healthy and kept on pasture. Triplicate samples from 2 healthy, adult horses (one Thoroughbred and one Swedish Warmblood) were used for the study of the variation of the method. These horses were stalled at the Large Animal Clinic and fed on a hay and oats diet.

\section{Preparation of leucocytes}

Blood was collected from the jugular vein into Vacutainer ${ }^{\circledR}$ tubes (Becton Dickinson, Meylan, France), with EDTA as anticoagulant, and immediately transported to the laboratory. In the study of the variation of the method, triplicate blood samples were drawn from 2 horses. Preparation of leucocytes and phagocytosis assays were done independently for each of the samples.

For lysis of red blood cells, $1 \mathrm{ml}$ of blood with EDTA was added to $9 \mathrm{ml}$ of Ortho-mune ${ }^{\mathrm{TM}}$ Lysing Reagent (Ortho Diagnostic Systems, Raritan, NJ, USA) in 10-ml tubes. From each animal, 3-5 $\mathrm{ml}$ of blood was prepared. The tubes were gently turned and incubated at room temperature $\left(22^{\circ} \mathrm{C}+/-5^{\circ} \mathrm{C}\right)$ until lysis was complete (usually after 5 to 10 minutes). The samples were centrifuged at 1000 RPM for 5 minutes. The cell pellet was resuspended carefully with a micropipette, avoiding air bubble formation, in $1 \mathrm{ml}$ Gey's buffer. All cells from each animal were pooled and Gey's buffer was added 
to a total volume of $10 \mathrm{ml}$. The cells were washed by centrifugation at 1000 RPM for 5 $\mathrm{min}$. The pellet was resuspended in $1 \mathrm{ml}$ Gey's buffer and immediately put on ice.

Neutrophils were counted in a Bürker chamber after staining with Türk's solution (Diagnostica Merck, Darmstadt, Germany). In the Swedish Standardbred horse, the normal value of eosinophils is $0-5 \%$ of the total white blood cells, and of monocytes $0-3 \%$ (Reference values from the Department of Clinical Chemistry, Faculty of Veterinary Medicine, Swedish University of Agricultural Sciences). The phagocytoses were therefore performed mainly by neutrophils.

\section{Preparation of opsonized yeast}

Baker's yeast cells (Saccharomyces cerevisiae) were heat-killed and labelled with fluorescein isothiocyanate (FITC) as previously described (Trowald-Wigh \& Thorén-Tolling 1990) and stored at $-18^{\circ} \mathrm{C}$. FITC-conjugated yeast cells were thawed, washed twice in Gey's buffer, counted, and diluted in Gey's buffer to a concentration of $5^{*} 10^{7}$ particles $/ \mathrm{ml}$ and were then stored in $1.5 \mathrm{ml}$ vials at $-18^{\circ} \mathrm{C}$. The yeast cells were opsonized with pooled horse serum or IgG for the phagocytosis assays as described below. Serum was pooled from 10 adult, healthy horses and stored at $-18^{\circ} \mathrm{C}$ in $2 \mathrm{ml}$ vials. Serum was thawed once and diluted in phosphate-buffered saline (PBS) to a concentration of $10 \%$. Freeze-dried rabbit-anti-yeast IgG (Dakopatts $\mathrm{AB}$, Hägersten, Sweden) was diluted in PBS to a concentration of $0.2 \mathrm{mg} / \mathrm{ml}$.

FITC-conjugated yeast $\left(5^{*} 10^{7}\right.$ particles $\left./ \mathrm{ml}\right)$ was mixed with serum $(10 \%)$ or with $\operatorname{IgG}(0.2$ $\mathrm{mg} / \mathrm{ml}$ ) at equal volumes and incubated for 30 $\min$ at $37^{\circ} \mathrm{C}$. The suspensions were then washed in Gey's buffer twice. Finally, the yeast cells were suspended in Gey's buffer and counted in a Bürker chamber after being passed through a $0.33 \mathrm{~mm}(29 \mathrm{G})$ injection needle (Becton Dickinson Insulin Syringe Ltd, Dublin,
Ireland) in order to separate cell aggregates. The concentration was adjusted to $1.0^{*} 10^{8}$ particles $/ \mathrm{ml}$. These batches of serum-opsonized or IgG-opsonized FITC-conjugated yeast cells were prepared once, stored in $0.5 \mathrm{ml}$ vials at $-18^{\circ} \mathrm{C}$ and used for all further phagocytoses. Within $72 \mathrm{~h}$ before each phagocytosis assay, frozen opsonized yeast cells were thawed and the concentration was checked after they had been passed through a $0.33 \mathrm{~mm}$ injection needle.

\section{Phagocytosis assay}

One ml of Hank's Balanced Salt Solution (HBSS, National Veterinary Institute, Uppsala, Sweden) was added to $5 \mathrm{ml}$ polypropylene test tubes (Becton Dickinson Labware, Lincoln Park, NJ, USA) on ice. Volumes corresponding to $7.5^{*} 10^{6}$ opsonized yeast cells of each opsonization ( $10 \%$ pooled adult horse serum, and 0.2 $\mathrm{mg} / \mathrm{ml} \mathrm{IgG}$, respectively) were added to 2 tubes for each horse and opsonization. $1.6^{*} 10^{6}$ neutrophils were added to every sample. This ratio was chosen after preliminary studies (data not shown). One of the samples of each opsonization was incubated with end-over-end rotation at $37^{\circ} \mathrm{C}$ for $15 \mathrm{~min}$ and the other was used as a negative phagocytosis control by immediate termination of phagocytosis. Phagocytosis was terminated in all samples by adding $3 \mathrm{ml}$ cold $\left(4^{\circ} \mathrm{C}\right) 0.02 \%$ EDTA in PBS and the cells were stored embedded in ice until analysed within 3 h. On every test occasion, serum- and IgG-opsonized yeast controls (without addition of leucocyte suspension) were prepared.

Directly before analysis, each sample was shaken to remove adhered neutrophils from the surface of the tube, passed through a $0.33 \mathrm{~mm}$ $(29 \mathrm{G})$ injection needle to separate aggregates of blood cells and/or yeast particles, and divided in 2 parts. One part was used for quenching of fluorescence from yeast cells not engulfed by phagocytes with trypan blue solution 
a

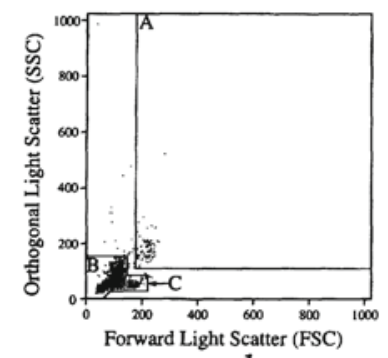

$\mathrm{d}$

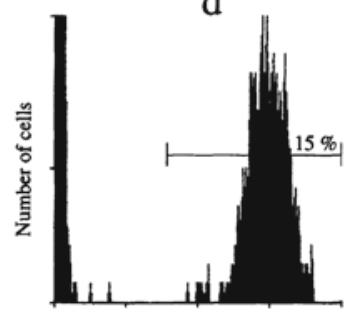

FITC fluorescence b

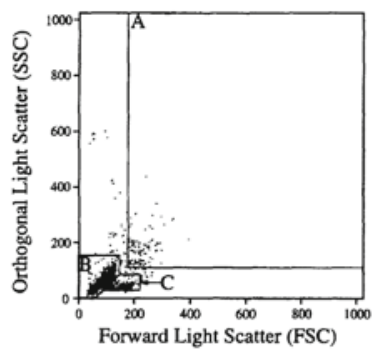

e

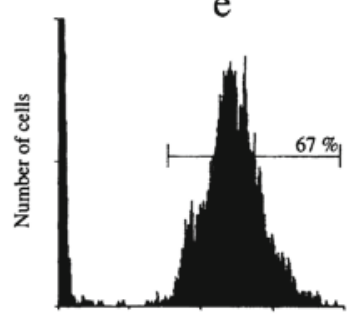

FITC fluorescence

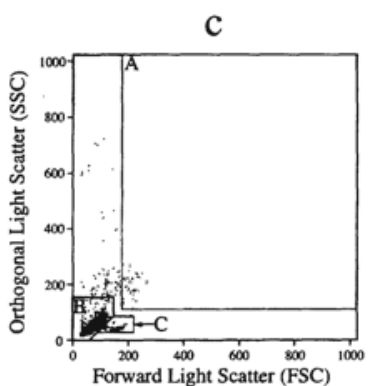

f

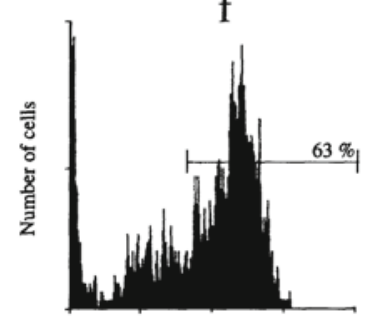

FrTC fluorescence

Figure 1. Flow cytometry data. The upper panel shows dot-plots of the FSC (size) and SSC (granularity) properties of samples incubated for $0 \mathrm{~min}(1 \mathrm{a}), 15 \mathrm{~min}(1 \mathrm{~b})$ and $15 \mathrm{~min}$ followed by trypan blue quenching for 7 $\min (1 \mathrm{c})$. The windows used for evaluation of the frequencies of neutrophils (A), yeast cells (B) and lymphocytes (C) are indicated. Note the heterogeneity in the scatter properties due to ingestion of yeast cells in Fig. 1b and the shift of neutrophils out of the neutrophil window in Fig. 1c. The lower panels show histograms of the FITC fluorescence of cells in the neutrophil window (A) in the dot-plot above each histogram. Events scored as positive for FITC fluorescence are indicated by a bar. The scales of the Y-axes are not uniform in Fig. $1 \mathrm{~d}$-f. After 0 min of incubation (1d) the positive events consist of aggregates of yeast cells. After 15 min of incubation and without trypan blue quenching (1e), the positive events are neutrophils with yeast cells attached and/or ingested and aggregates of yeast cells. After $15 \mathrm{~min}$ of incubation followed by trypan blue quenching (1f), only neutrophils with yeast cells ingested are scored positive.

(Bjerknes \& Bassøe 1984). For quenching, 250 $\mu \mathrm{l}$ of the sample was stained with $113 \mu \mathrm{l}$ trypan blue (Merck, München, Germany), $2.5 \mathrm{mg} / \mathrm{ml}$, for 5 minutes or more at room temperature.

\section{Flow cytometric analysis of phagocytosis}

Flow cytometric analysis was conducted with a FACStar ${ }^{\text {PLUS }}$ flow cytometer (Becton Dickinson Immunocytometry Systems, San José, CA, USA) with standard optical equipment. The diameter of the tube was $500 \mu \mathrm{m}$, thus allowing activated, expanded phagocytes to pass without problems.
For analysis of phagocytosis, measures of forward scatter (FSC), side scatter (SSC) and green fluorescense (FL1) were collected for each event (i.e., for each cell or cell aggregate passing through the laser beam). FSC indicates the size, and SSC the granularity of each cell. Cells with similar properties can thus be identified. From each sample, 50,000 events were collected before and 50,000 after trypan blue quenching of fluorescence from yeast cells not engulfed by phagocytes, (i.e., attached or free). Three gates were placed in the FSC-SSC dotplot to identify granulocytes, yeast cells and 
a

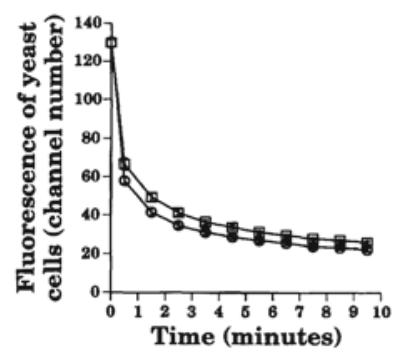

b

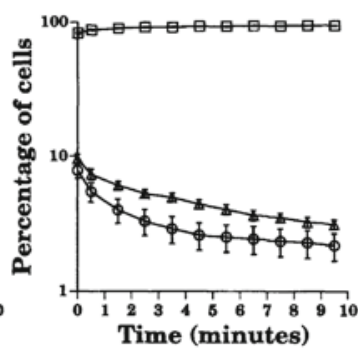

c

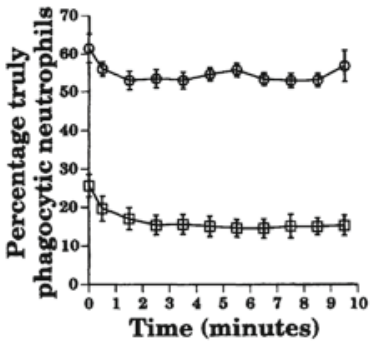

Figure 2. The kinetics of trypan blue quenching. Fig. 2a shows the mean fluorescence of serum-opsonized $(O)$ and IgG-opsonized $(\square)$ yeast cells (b in Fig. 1), quenched with trypan blue for various lengths of time $(\mathrm{n}=5)$. In Fig. $2 b$ the mean percentages of cells in the neutrophil window ( $\triangle$, a in Fig. 1), the yeast cell window ( $\square$, b in Fig. 1) and the lymphocyte window $(\mathrm{O}, \mathrm{c}$ in Fig. 1), as a function of time after addition of trypan blue are shown $(n=5)$. Fig. $2 c$ depicts the mean percentages of truly phagocytic neutrophils in serum-opsonized $(O)$ and IgGopsonized $(\square)$ samples during the course of trypan blue quenching $(n=5)$. Error bars represent standard errors of the mean.

lymphocytes, as indicated in Fig. 1. The frequencies of activated neutrophils, defined as neutrophils in unquenched samples which had either attached or ingested one or more yeast cells and thereby showed green fluorescence, were determined. The same calculations were performed on data from quenched samples, whereby the frequencies of truly phagocytic neutrophils could be determined.

In the study of the quenching dynamics, data were collected starting immediately after addition, starting after $60 \mathrm{sec}$, and then starting at $60-\mathrm{sec}$ intervals up to $9 \mathrm{~min}$. The software used for acquisition (FACStarPLUS Software version 2.01) did not allow a true time parameter to be collected. Off-line analysis was performed using LYSYS version 1.62. Cells were sorted onto glass slides for visual inspection in a Nikon Microphot fluorescence microscope (Nippon Kogaku K.K., Tokyo, Japan), using the normal-recovery sort mode.

\section{Statistical methods}

Mean values, standard errors of the mean and coefficient of variation were calculated conventionally.

\section{Results}

\section{Incubation and trypan blue quenching}

The incubation and the quenching with trypan blue affected the FCM data obtained (Fig. 1). Incubation of neutrophils with opsonized yeast cells resulted in heterogeneity in the scatter properties of the neutrophils. It was noted that the population of neutrophils was slightly shifted towards lower FSC values after trypan blue quenching, and therefore the effects on different populations of cells and, most importantly, the frequency of activated neutrophils, were studied. For this purpose, data were acquired during the course of quenching. The fluorescence of free yeast cells declined rapidly during the first few minutes after the addition of trypan blue and reached a plateau after approximately $5 \mathrm{~min}$ (Fig. 2a). As also seen in Fig. 2a, there was a tendency towards more rapid quenching of serum-opsonized than of IgG-opsonized yeast cells. The frequency of 
Table 1. Data on the variation of the method. Triplicate samples were prepared and analysed from two horses. The percentages of truly phagocytic cells and the coefficients of variation are given.

\begin{tabular}{lccccc}
\hline Opsonization & Horse & \multicolumn{3}{c}{ \% truly phagocytic cells } & $\begin{array}{c}\text { Coeff. of } \\
\text { Variation }\end{array}$ \\
\cline { 2 - 5 } & & sample 1 & sample 2 & sample 3 & \\
\hline PS & A & 48 & 39 & 56 & 0.18 \\
PS & B & 75 & 70 & 51 & 0.13 \\
IgG & $\mathrm{A}$ & 8 & 9 & 14 & 0.32 \\
IgG & B & 15 & 26 & 23 & 0.27 \\
\hline
\end{tabular}

cells inside the neutrophil window (A in Fig.1) declined during trypan blue quenching (Fig. $2 b)$, as a result of effects of trypan blue dye on the living cells, changing their size and/or granulation, and thereby their forward and side scatter values. This did not alter the frequency of activated cells (Fig. 2c).

\section{The variation of the method}

Data on the variation of the method are presented in Table 1. The coefficient of variation ranges from to 0.13 to 0.31 .

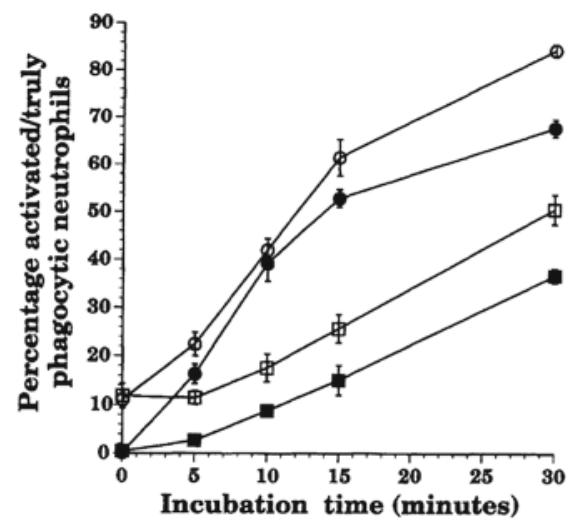

Figure 3. Kinetics of phagocytosis of yeast cells by neutrophils. Serum-opsonized unquenched $(O)$ and quenched $(\bullet)$ samples. IgG-opsonized unquenched $(\square)$ and quenched $(\square)$ samples (n=5). Error bars represent standard errors of the mean.

\section{The attachment and ingestion kinetics}

In the kinetic study, values for unquenched and quenched samples followed each other with only minor variations, indicating that the number of neutrophils with only attached yeast cells was small (Fig. 3). The phagocytic process was completed more rapidly when serum was used as an opsonin than with IgG (Fig. 3). After 15 min of incubation, about $60 \%$ of the neutrophils were activated when serum-opsonized yeast cells were used. The corresponding value for IgG-opsonized yeast cells was $25 \%$ (Fig. 3). The frequencies of neutrophils declined after 30 min of incubation and visual inspection after flow-cytometric sorting revealed that many cells were disrupted after this incubation time. In the samples terminated immediately, $\sim 10 \%$ activated and $\sim 0 \%$ truly phagocytic neutrophils were detected, indicating the effects of aggregated yeast cells.

\section{Effects of aggregates of yeast cells}

The effects of aggregates of yeast cells on the outcome of the FCM analysis are illustrated in a computer-simulation of the errors in frequency determination (Fig. 4). These aggregates were scored as false-positive activated neutrophils in unquenched samples (Fig. 4a) and were falsely interpreted as neutrophils negative for true phagocytosis in samples quenched with trypan blue (Fig. 4b). The effect of this will be that the error in frequency deter- 

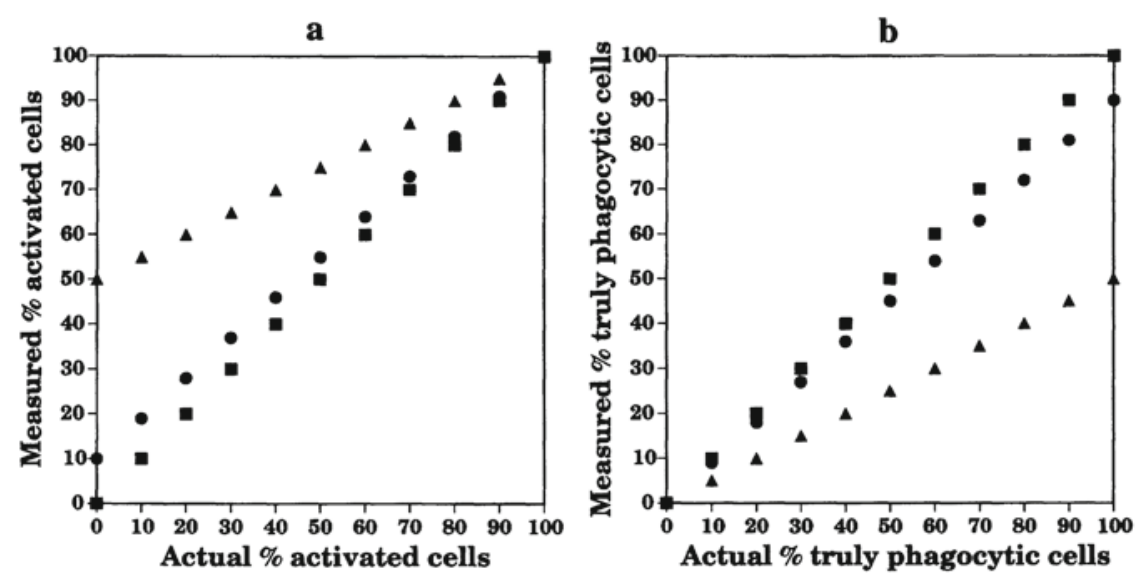

Figure 4. Computer-simulation of the effects of contaminating yeast cell aggregates in the neutrophil window (a in Fig. 1). Fig. 4a shows the deviations from true values of activated cells $(\mathbf{\square})$ when $10 \%(\bullet)$ and $50 \%(\mathbf{\Delta})$ of the events in the neutrophil window are yeast cell aggregates, while Fig. $4 \mathrm{~b}$ shows the effects on the percentages of truly phagocytic neutrophils after trypan blue quenching, with symbols as in Fig. 4a.

mination due to aggregates of yeast cells will be larger in samples with low frequencies of positive cells for unquenched samples. In quenched samples, on the other hand, the error will be larger in samples with high frequencies of positive cells.

\section{Discussion}

This methodological flow-cytometric study was performed in order to establish rapid and reliable methods for our future studies of phagocytosis by equine neutrophils.

As shown in Fig. 2a, the slope of the quenching curve is steeper shortly after trypan blue addition than after several minutes. This indicates that 5-9 min after addition of trypan blue, the method is not very sensitive to minor variations in the duration of quenching. The difference between quenched and unquenched samples can mainly be attributed to aggregates of yeast cells contaminating the neutrophil window (A in Fig. 1). This, taken together with the observation that the alterations in cell populations do not affect the determined frequencies of neutrophils that are actively phagocytic, leads to the conclusion that an accurate evaluation of frequencies of actively phagocytic neutrophils can be made between 5 and 9 min after addition of trypan blue. Trypan blue quenching has been compared with quenching with crystal violet in studies by other authors (Bjerknes \& Bassøe 1984, Hed et al. 1987), and trypan blue has been shown not to quench fluorescence of ingested yeast cells (Hed et al. 1987) or zymosan particles (Bjerknes \& Bassøe 1984), in contrast to crystal violet. The design of the test presented here permitted differentiation between: (a) neutrophils with ingested and/or attached yeast particles, (b) neutrophils with particles only attached and (c) neutrophils with no attached or ingested particles.

The data on the variation of the method indicate that the method is useful to investigate differences between groups of horses. It is recommended that triplicate samples are analyzed when individual horses are to be examined. 
The phagocytoses of unquenched and quenched samples follow each other closely and show only minor differences as a function of duration of phagocytosis. This indicates that the attachment phase is rapidly completed, and that the difference between unquenched and quenched samples mainly reflects quenching of yeast cell aggregates, with only a minor contribution of neutrophils with attached particles only. The kinetics of phagocytosis of equine neutrophils is similar to that of porcine neutrophils in that the phagocytosis of serum-opsonized yeast cells occurs more rapidly than that of IgG-opsonized yeast cells (JensenWaern et al. 1994). In the present study higher percentages of cells were activated and truly phagocytic when serum-opsonized yeast cells were used than with the use of IgG-opsonized yeast cells. This has previously been reported in studies on pigs (Jensen-Waern et al. 1994), while no differences have been found in dogs (Trowald-Wigh \& Thorén-Tolling 1990), and human cells have shown the opposite tendency (Hed \& Stendahl 1982). Because of the loss of neutrophils after $30 \mathrm{~min}$ of incubation, $15 \mathrm{~min}$ was chosen as the time of incubation in the subsequent studies. The aggregation of yeast cells poses problems regarding accurate determination of frequencies of activated and truly phagocytic neutrophils. In our experience these problems can be overcome by passing samples through a syringe immediately before analysis. With the ratio of 5 yeast cells/neutrophil used in this study and disruption of aggregates, accurate analysis of phagocytosis by flow cytometry can be achieved. To keep track of the effects of yeast cell aggregates, it is preferable to analyse negative controls (samples where phagocytosis has been immediately terminated) for each horse and opsonization used. Foerster \& Wolf (1990) have previously performed flow cytometric studies of equine neutrophils. In their method fluorescent latex beads were used as the material to be phagocytosed. By virtue of the uniform fluorescence of the latex beads, the method allows determination of the number of ingested particles/cell. In the method presented here, less quantitative information is obtained, on account of the non-uniform fluorescence of the yeast cells. However, the yeast cells are biological material and thus better mimic the in vivo situation. The approach of using biological particles opens possibilities for further developments, e.g., the study of phagocytosis of microorganisms. Phagocytosis of Ehrlichia risticii by equine neutrophils has been studied previously by flow cytometry (Messick \& Rikihisa 1993) and a method for studies of fluorophorelabelled Rhodococcus equi would be useful. Another possibility may be to use living yeast cells for a flow-cytometric study of the capacity for intracellular killing at the single-cell level (Martin \& Bhakdi 1991) as a refinement of bulk measurements of chemiluminescence. The assay presented here provides a means for rapid analysis of the phagocytic properties of equine granulocytes. This is useful when a large number of samples are to be investigated, e.g., in studies of herds.

\section{Acknowledgements}

The financial support from the Swedish Horse Race Totalizator Board (ATG) is gratefully acknowledged. The flow cytometer used in this study was financed by a grant from the Knut and Alice Wallenberg foundation.

\section{References}

Babior B: Oxygen dependent microbial killing by phagocytosis. New Engl. Med. J. 1978, 269, 659668.

Bernoco M, Liu I, Wuest-Ehlert C, Miller M, Bowers $J$ : Chemotactic and phagocytic function of peripheral blood polymorphonuclear leucocytes in newborn foals. J. Reprod. Fert. Suppl. 1987, 35, 599-605.

Bjerknes R, Bassøe C-F: Phagocyte C3-mediated attachment and internalization: flow cytometric studies using a fluorescence quenching technique. Blut 1984, 49, 315-323. 
Calvelli T, Denny T, Paxton H, Gelmann R, Kagan J: Guideline for flow cytometric immunophenotyping: A report from the national institute of allergy and infectious diseases, division of AIDS. Cytometry 1993, 14, 702-715.

Campana D: Applications of cytometry to study acute leukemia: In vitro determination of drug sensitivity and detection of minimal residual disease. Cytometry 1994, 18, 68-74.

Foerster R, Wolf G: Phagocytosis of opsonized fluorescent microspheres by equine polymorphonuclear leukocytes. J. Vet. Med. B 1990, 37, 481490.

Hed J, Halldén G, Johansson S, Larsson P: The use of fluorescence quenching in flow cytofluorometry to measure the attachment and ingestion phases in phagocytosis in peripheral blood without prior cell separation. J Immunol Methods 1987, 101, 119-125.

Hed J, Stendahl O: Differences in the ingestion mechanisms of IgG and $\mathrm{C} 3 \mathrm{~b}$ particles in phagocytosis by neutrophils. Immunology 1982, 45, 727-736.

Jacobsen K, Gintz T, Reed S, Newbry J, Bayly W, Perryman $L$, Leid $R$ : Isolation of equine neutrophils and analysis of functional characteristics by chemiluminescence and bactericidal assays. Am. J. Vet. Res. 1982, 43, 1912-1916.

Jensen-Waern M, Johannisson A, Trowald-Wigh G, Ederoth M: Methods for evaluation of the adhesive and phagocytic capacities of porcine granulocytes. J. Vet. Med. B 1994, 42, 625-638.

Leblanc M, Pritchard E: Effects of bovine colostrum, foal serum immunoglobulin concentration and intravenous plasma transfusion on chemiluminescence response of foal neutrophils. Anim. Genet. 1988, 19, 435-445.

Magnusson U, Jonsson K: A method for the accurate measurement of opsonic activity in uterine secretions of the mare. Theriogenology 1991, 36, 737 747.

Martin E, Bhakdi S: Quantitive analysis of opsonophagocytosis and of killing of Candida albicans by human peripheral blood leukocytes by using flow cytometry. J. Clin. Microbiol. 1991, 29, 2013-2023.

Matsson P, Fossum C, Larsson B: Evaluation of flow cytometry and fluorescence microscopy for the estimation of bovine mononuclear phagocytes. J. Immunol. Methods. 1985, 78, 13-24.

McGuire T, Crawford T, Halowell A, Macomber L: Failure of colostral immunoglobulin transfer as an explanation for most infections and deaths of neonatal foals. J. Amer. vet. Med. Assoc. 1977, 170, 1302-1304.

Messick J, Rikihisa Y: Characterization of Ehrlichia risticii binding, internalization, and proliferation in host cells by flow cytometry. Infect. Immun. 1993, 61, 3803-3810.

Morris D, Gaulin G, Strzemienski P, Spencer P: Assessment of neutrophil migration, phagocytosis and bactericidal capacity in neonatal foals. Vet. Immunol. Immunopathol. 1987, 16, 173-184.

Platt H: Etiological aspects of perinatal mortality in the Thoroughbred. Equine vet. J. 1973, 5, 116-20.

Prescott J: Immunodeficiency and serious pneumonia in foals: the plot thickens. Equine vet. J. 1993, $25,88-89$.

Root RK, Metcalf $J A: \mathrm{H}_{2} \mathrm{O}_{2}$ release from human granulocytes during phagocytosis. Relationship to superoxide anion formation and cellular catabolism of $\mathrm{H}_{2} \mathrm{O}_{2}$ : studies with normal and cytochalasin B-treated cells.. J. clin. Invest. 1977, 60, 1266-79.

Saad A, Hageltorn M: Flow cytometric characterization of bovine blood neutrophil phagocytosis of fluorescent bacteria and zymosan particles. Acta vet. scand. 1985, 26, 289-307.

Stossel T: Medical progress: phagocytosis. New Engl. med. J. 1974, 28, 717-723.

Takai S, Morozumi Y, Higashiyama S, Tsubaki S: Nitroblue tetrazolium reduction by neutrophils of newborn foals, adult horses, and a foal infected with Rhodococcus (Corynebacterium) equi. Jpn. J. vet. Sci. 1986, 48, 405-408.

Thuvander A, Norrgren L, Fossum C: Phagocytic cells in blood from rainbow trout, Salmo gairdneri (Richardson), characterized by flow cytometry and electron microscopy. J. Fish Biol. 1987, 31, 197-208.

Trowald-Wigh G, Thorén-Tolling K: Phagocytosis induced by yeast cells in canine granulocytes: a methodological study. Acta vet. scand. 1990, 31, 87-95.

\section{Sammanfattning}

Flödescytometriska studier av fagocytosförmågan hos ekvina neutrofiler

Den fagocyterande förmågan hos hästens neutrofiler studerades med flödescytometri. Kinetiken för adhesion och upptag av jästceller undersöktes. Fagocytosförloppet slutfördes snabbare när serum-opsoniserade jästceller användes än när IgG-opsoniserade 
jästceller var målpartiklar. Släckning med trypanblått ger möjlighet att eliminera falskt positiva händelser, som beror på jästaggregat utanför neutrofilen. Släckningen orsakade en förlust av celler med neutrofilers ljusspridningsegenskaper, men detta påverkade inte de uppmätta frekvenserna av fagocyterande neutrofiler. Endast smärre skillnader i fagocy- toskinetiken kunde ses när släckta och osläckta prover jämfördes. Det konkluderas att flödescytometri är väl lämpat för studier av ekvina neutrofilers fagocytos av jästceller. Metodens största fördel är att man snabbt kan analysera stora provserier, vilket möjliggör undersökningar av hela besättningar.

(Received May 15, 1995; accepted August 29, 1995).

Reprints may be obtained from: A. Johannisson, Department of Pathology, Faculty of Veterinary Medicine, Swedish University of Agricultural Sciences, P.O. Box 7028, S-750 07 Uppsala, Sweden. 